\title{
Physicochemical Investigations of Homeopathic Preparations: A Systematic Review and Bibliometric Analysis-Part 1
}

\author{
Sabine D. Klein, PhD, Sandra Würtenberger, MSc, Ursula Wolf, MD, \\ Stephan Baumgartner, $\mathrm{PhD}^{1,3,4}$ and Alexander Tournier, $\mathrm{PhD}^{1,5}$
}

\section{Abstract}

Objectives: The last systematic review of physicochemical research performed on homeopathic preparations was published in 2003. The aim of the study is to update and expand the current state of knowledge in the area of physicochemical properties of homeopathic preparations. In part 1 of the study, we aim to present an overview of the literature with respect to publication quality and methods used. In part 2, we aim to identify the most interesting experimental techniques. With this, we aim to be in a position to generate meaningful hypotheses regarding a possible mode of action of homeopathic preparations.

Methods: A two-step procedure was adopted: (1) an extensive literature search, followed by a bibliometric and quality analysis on the level of publications and (2) a thorough qualitative analysis of the individual physicochemical investigations found. In this publication, we report on step (1). We searched major scientific databases to find publications reporting physicochemical investigations of homeopathy from its origin to the end of 2015 . Publications were assessed using a scoring scheme, the Manuscript Information Score (MIS). Information regarding country of origin of the research and experimental techniques used was extracted.

Results: We identified 183 publications (compared to 44 in the last review), 122 of which had an MIS $\geq 5$. The rate of publication in the field was $\sim 2$ per year from the 1970s until 2000. Afterward, it increased to over 5.5 publications per year. The quality of publications was seen to increase sharply from 2000 onward, whereas before 2000, only 12 (13\%) publications were rated as "high quality" (MIS $\geq 7.5)$; 44 (48\%) publications were rated as "high quality" from 2000 onward. Countries with most publications were Germany $(n=42$, $23 \%)$, France $(n=29,16 \%)$, India $(n=27,15 \%)$, and Italy $(n=26,14 \%)$. Techniques most frequently used were electrical impedance (26\%), analytical methods (20\%), spectroscopy (20\%), and nuclear magnetic resonance $(19 \%)$.

Conclusions: Physicochemical research into homeopathic preparations is increasing both in terms of quantity and quality of the publications.

Keywords: systematic review, homeopathy, physics, very high dilutions, serially diluted and agitated solutions, ultrahigh aqueous dilutions

\footnotetext{
${ }^{1}$ Institute of Complementary Medicine, University of Bern, Bern, Switzerland.

${ }^{2}$ Scientific \& Regulatory Affairs, Hevert-Arzneimittel GmbH \& Co. KG, Nussbaum, Germany.

${ }^{3}$ Society for Cancer Research, Arlesheim, Switzerland.

${ }^{4}$ Institute of Integrative Medicine, University of Witten/Herdecke, Witten, Germany.

${ }^{5}$ Homeopathy Research Institute, London, United Kingdom.
}

(C) Sabine D. Klein et al., 2018; Published by Mary Ann Liebert, Inc. This Open Access article is distributed under the terms of the Creative Commons Attribution Noncommercial License (http://creativecommons.org/licenses/by-nc/4.0), which permits any noncommercial use, distribution, and reproduction in any medium, provided the original authors and the source are properly cited. 


\section{Introduction}

$\mathbf{H}$ OMEOPATHY IS A POPULAR complementary or alternative treatment modality in Europe ${ }^{1}$ and India, ${ }^{2,3}$ while less so, but with an increasing demand in the United States. ${ }^{4}$ Homeopathic remedies, produced by alternate sequential dilution and succussion, have been shown to be effective in plant experiments, ${ }^{5-7}$ animal models, ${ }^{8}$ as well as clinical trials involving humans. ${ }^{9,10}$

The mode of action underlying specific effects of highly diluted homeopathic preparations could not yet be established, which strongly hampers the acceptance of homeopathy. A variety of models have been proposed. These can be categorized as local models ${ }^{11-18}$ and nonlocal models. ${ }^{19-23}$ For recent review of the theory, the reader is referred to the reviews by Schulte and Endler ${ }^{24}$ and Bellavite et al. ${ }^{25}$

However, any theoretical model needs to be supported by experimental evidence. The aim of this systematic review is to compile and interpret previously published research on physicochemical investigations of homeopathically potentized preparations, to refine existing hypotheses, and generate new ones, and so direct future experiments. It is also an update of previous systematic reviews of physicochemical investigations ${ }^{26,27}$ and a specification of a broader bibliometric evaluation of homeopathic basic research in general. ${ }^{28}$

In this article, we present the literature search, quality analysis, and bibliometric description on the level of publications. In a second step, in a follow-up publication, individual investigations will be extracted from the high-quality publications and analyzed in detail, with the aims of identifying most interesting experimental techniques, identifying empirical evidence (if any) of specific physicochemical features of homeopathic preparations, determining most promising areas of research, and generating hypotheses regarding a possible mode of action of homeopathic preparations.

\section{Methods}

\section{Protocol and registration}

This review was planned and conducted in accordance with the Preferred Reporting Items for Systematic Reviews and Meta-Analyses (PRISMA) guidelines. ${ }^{29}$ The protocol was not registered in any database; as such databases are geared toward registering health-related systematic reviews.

We made the distinction between "publications" and "investigations". A publication can report on results of several different investigations. On the other hand, a single investigation can be presented in several publications. To simplify the analysis, the procedure was split in two parts. This study focuses its analysis per "publications"- - a deeper per "investigation" analysis will be presented in a subsequent publication.

\section{Eligibility criteria}

To be eligible for this systematic review, investigations reported in the publications needed to

- be experimental

- investigate physicochemical properties of homeopathic preparations

- investigate potency levels $\geq 6 \mathrm{x}$ or $3 \mathrm{c}$

- be published before the end of 2015 .
Publication types included papers in peer-reviewed and not peer-reviewed journals, theses, books, book sections, and conference proceedings. Conference abstracts were excluded, because their word limits did not allow for a detailed description of the methodology and results.

There was no language restriction (papers in English, German, French, and Russian were evaluated).

Publications were excluded, if they

- described experiments with enzymes, bacteria, cells, plants, animals, or humans

- described mathematical models or theoretical thought experiments

- were a translation of another publication in a different language.

Publications that described several experiments were included if at least one experiment fulfilled the inclusion criteria.

\section{Information sources}

The following databases were searched, from the beginning of each database until the end of 2015: HomBRex, PubMed, Web of Science, Embase, and Scopus. Personal literature collections were also included.

\section{Search}

Search terms were as follows: homeopath*, high dilutions, very dilute aqueous solutions, very high dilutions, ultrahigh aqueous dilutions, extremely diluted solutions, extremely diluted aqueous solutions, ultramolecular aqueous dilutions, and serially diluted and agitated solutions. These were combined with physicochemistry keywords.

In HomBRex, the search was by Field "Physical chemistry."

In Web of Science, the search strategy was as follows: Keywords: Homeopath*. Restricted to Research areas: chemistry OR microscopy OR biophysics OR physics OR materials science OR science technology other topics OR instruments instrumentation OR medical lab technology. In SCOPUS and PubMed; the search terms were as follows: ([homeopath* or homoeopath* or "ultra high dilution"' OR "serial*agit*"]) AND (NMR OR Spectrom* or spectrosc* or conducti* OR AFM OR Thermolumi* OR lumine* OR dielectric OR densitometry OR refractometry OR microcal* OR ultrasound OR "Surface Tension").

The International Journal of High Dilution Research was searched by scanning the table of contents for all years available.

The personal literature collection of S.B. was searched by the following keyword: Phys*.

Further references were added from earlier reviews. ${ }^{26,27}$

The search was performed by two authors independently (S.B. and A.T.) and then combined in EndNote.

\section{Manuscript Information Score}

Full-text papers were screened for inclusion and exclusion criteria (see above). Papers matching these criteria were then evaluated according to a Manuscript Information Score (MIS). The present MIS scoring scheme is based upon an MIS used for the rating of bioassay publications, ${ }^{5-7}$ which was adapted for the rating of physicochemical publications, 
defined at the beginning of the review. The MIS used in this review provides a score assessing the quality of reporting, with items specifically relevant for physicochemical research into homeopathic preparations.

Five assessment areas were each attributed a score between 0 and 2, providing a final maximum MIS score of 10. The categories considered were as follows: experimental procedure, materials, measuring instruments, potentization, and controls. The specifics of the scoring scheme are presented in Table 1.

Scoring was performed by two reviewers independently. Differences in MIS scores greater than one were resolved by discussion between the reviewers. No reviewer scored his own publications. Authors of the publications were not contacted for obtaining additional (missing) data.

\section{Data items}

The following data were extracted from each publication:

- Publication type (Peer-reviewed journal, Not peerreviewed journal, Journal peer review unknown, Conference proceedings, Book or book section, Thesis)

- Publication year

- Techniques used, categorized in 11 groups: Electrical impedance, Analytical methods, Spectroscopy, Nuclear Magnetic Resonance (NMR), Imaging methods, Calorimetry, Electrochemistry, Luminescence, Chromatography, Raman spectroscopy, Various physical
- Country of origin (the country of the corresponding author was selected when authors were from several countries)

- MIS (see above).

\section{Results}

Three hundred and three references were identified through searching databases and personal libraries. For 14 references, no full text was available (some books could not be found in the libraries accessible to us, and some $\mathrm{PhD}$ theses could not be obtained in full text), such that only 289 could be retrieved in full text. Out of these 289 publications, 106 were excluded for various reasons (Fig. 1). Finally, 183 publications were included in this bibliometric evaluation ${ }^{11,12,16,30-209}$ (Fig. 1). The full list of included publications along with their associated MIS score, Country, Publications Type, and Methods used is provided as Supplementary Data (Supplementary Data are available online at www.liebertpub.com/acm).

\section{Publication type and journals}

Most papers appeared in peer-reviewed journals, with $68 \%$ of all publication peer reviewed. Seventy-three percent of the publications with an MIS $\geq 5$ were peer reviewed (Table 2). Table 3 presents the journals having published more than five publications. We see that the journal Homeopathy (formerly British Homeopathic Journal) has published the most with 24 publications in the field and has carried on publishing in recent years (17 publications from 2000 onward). Interestingly, the Journal of the American Institute of Homeopathy,

Table 1. Assessment of the Manuscript Information Content by the Manuscript Information Score

\begin{tabular}{|c|c|c|}
\hline & Score & Description \\
\hline Experimental procedure & $\begin{array}{l}1 \\
0\end{array}$ & $\begin{array}{l}\text { Detailed information is given as follows: } \\
\text { Timeline of preparations and measurements/time of measurement } \\
\text { Randomization, blinding } \\
\text { Number of replicates } \\
\text { Number of measurements } \\
\text { Treatment/handling of the samples after potentization } \\
\text { Only some details are described or few information about the setup is given } \\
\text { No information is given about the experimental setup }\end{array}$ \\
\hline Materials & $\begin{array}{l}2 \\
1 \\
0\end{array}$ & $\begin{array}{l}\text { All materials used in the experiments are described with trade name, etc. } \\
\text { Some materials used in the experiments are described or mentioned } \\
\text { No information is given about the materials used }\end{array}$ \\
\hline Measuring instruments & $\begin{array}{l}2 \\
1 \\
0\end{array}$ & $\begin{array}{l}\text { Measuring instruments are described in detail, operation mode, trade name, type, etc. } \\
\text { Measuring instruments are only mentioned } \\
\text { There is no information about measuring instruments in the paper }\end{array}$ \\
\hline Potentization & $\begin{array}{l}2 \\
1 \\
0\end{array}$ & $\begin{array}{l}\text { Potentization technique, date and time of potentization, and potentization medium } \\
\text { are described in detail } \\
\text { Some information about potentization technique is given } \\
\text { Ordered from company without further details-"Material 30c" } \\
\text { No information about potentization, only the potentized test substance is mentioned }\end{array}$ \\
\hline Controls & $\begin{array}{l}2 \\
1 \\
0\end{array}$ & $\begin{array}{l}\text { Detailed information (e.g. sterile distilled water from the same } \\
\text { batch of distilled water...) } \\
\text { Some information about the sort of control is given (e.g. water control) } \\
\text { Or other potency levels serve as control } \\
\text { Controls are not mentioned or done }\end{array}$ \\
\hline
\end{tabular}

Five assessment areas were given a score between 0 and 2, leading to a maximum of 10 points. Only studies with MIS $\geq 5$ were included in the review.

MIS, Manuscript Information Score. 
FIG. 1. PRISMA flow diagram of paper inclusion.

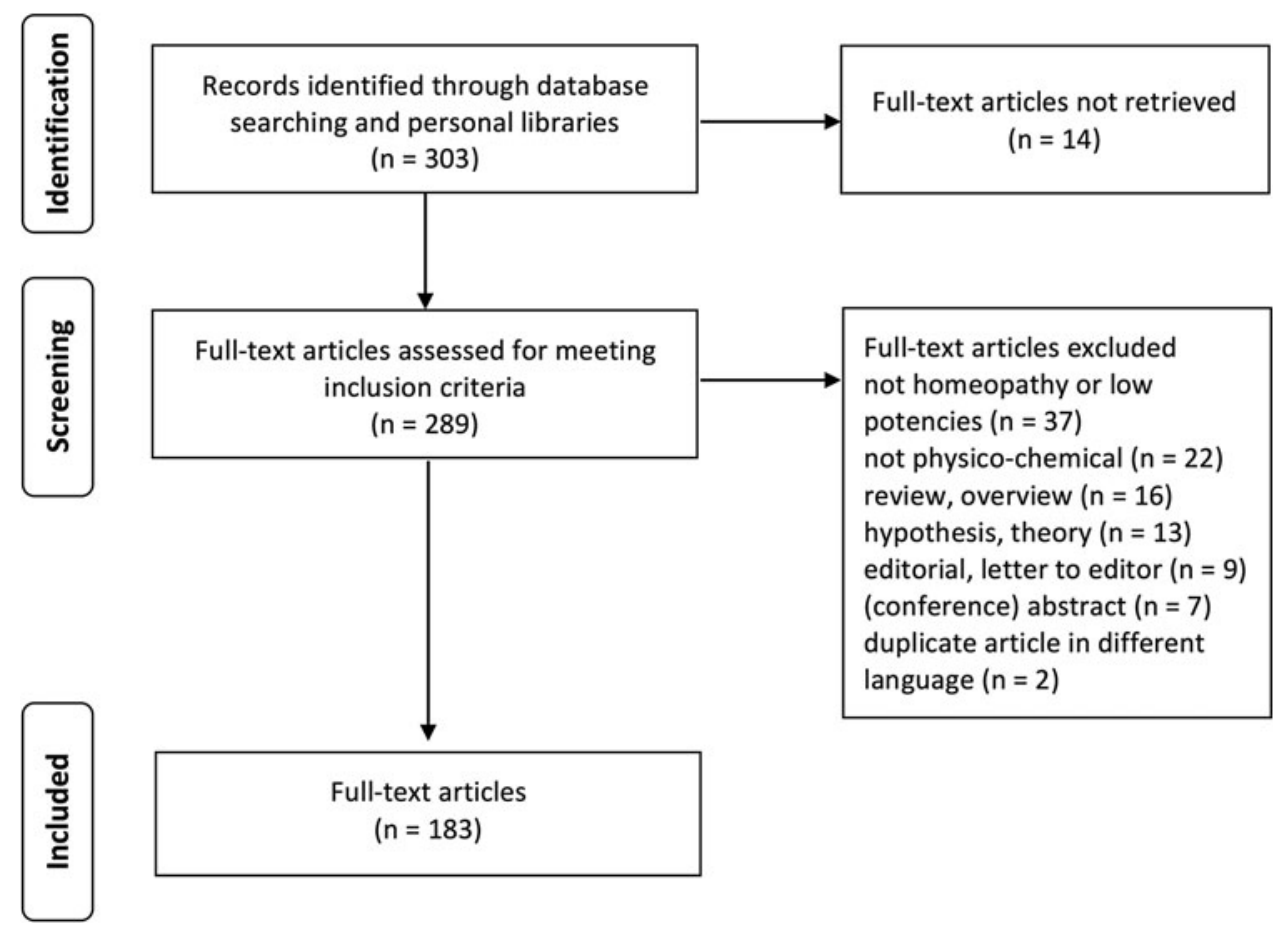

which published 11 papers in this field, has stopped publishing physicochemical research in recent years. Similarly, the Annales Homéopathiques Françaises has stopped publishing in this field (six publications before 2000). On the other hand, journals like the International Journal of High Dilution Research, the Journal of Thermal Analysis and Calorimetry, and the Journal of Molecular Liquids have been publishing in this field from 2000 onward (seven publications from 2000 onward each).

\section{Development over time}

Figure 2 presents the number of publications over time. The number of publications has been increasing markedly around 2000 from $\sim 2$ publications per year to over 5.5 publications per year from 2000 onward (see insert in Fig. 2). The first publication we found dates back to 1842 and was performed by a German author, Carl Mayrhofer, who studied the grinding of metals through solid trituration by microscopic investigation. ${ }^{158}$ The following publication was a French study, which appeared in $1935,{ }^{206}$ followed in 1936 by the first British publication. ${ }^{52}$

Table 2. Breakdown of Publications According to Type of Publication

\begin{tabular}{lccr}
\hline Publication type & MIS $<5$ & MIS $\geq 5$ & Total \\
\hline Peer-reviewed journal & 36 & 89 & 125 \\
Not peer-reviewed journal & 2 & 2 & 4 \\
Journal peer review unknown & 14 & 10 & 24 \\
Conference proceedings & 5 & 5 & 10 \\
Book or book section & 4 & 10 & 14 \\
Thesis & 0 & 6 & 6
\end{tabular}

MIS, Manuscript Information Score.

\section{Reporting quality}

The rate of agreement in the MIS-defined as one or less point difference between the two reviewers scoring the papers-was greater than $85 \%$. One hundred and twentytwo of the 183 publications $(67 \%)$ were scored with an MIS $\geq 5$ and rated as publication with "acceptable reporting quality." Fifty-six of the 183 publications (31\%) were scored with an MIS $\geq 7.5$ and rated as publication with "high reporting quality."

The quality of the papers, as determined by MIS $\geq 5$, has also risen sharply in recent years, with only $35 \%$ of publication in the 80 s having an MIS $\geq 5$ compared to $82 \%$ in the current decade (Fig. 2). Looking at the distribution of MIS scores over the years, we see that the average MIS score has increased significantly since 1990 from 4.2 to 6.9 (data not shown). Considering that $50 \%$ of publications were published in 2000 or after, it makes sense to look more closely at recent years. Before 2000, only 12 (13\%) publications had an MIS $\geq 7.5$ (defined as "high-quality"), with most publications having MIS scores around 4 (Fig. 3). The picture is considerably different from 2000 onward, where $44(48 \%)$ publications had an MIS $\geq 7.5$. On average, over the whole time range, $30 \%$ of publications had an MIS $\geq 7.5$.

\section{Geographic distribution}

Figure 4 presents the breakdown of publications by country (more specifically, the country of the corresponding author). Most publications came from Germany with 42 publications (23\% of all publications), France with 29 publications (16\%), India with 27 publications (15\%), and Italy with 26 publications (14\%). Germany and Italy have been publishing the most publications with MIS $\geq 5$ (25 each, i.e., 20\%). From 2000 onward, the breakdown per country is somewhat 
Table 3. Journals Publishing More Than Five Physicochemical InVESTIGATIONS OF HoMeOPATHIC PREPARATIONS-BEFORE 2000 AND FROM 2000 ONWARDS

\begin{tabular}{lccc}
\hline Journal & $\begin{array}{c}\text { Before } \\
2000\end{array}$ & $\begin{array}{c}2000 \\
\text { Onward }\end{array}$ & Total \\
\hline $\begin{array}{l}\text { Homeopathy } \\
\text { Journal of the American } \\
\quad \text { Institute of Homeopathy }\end{array}$ & 11 & 17 & 24 \\
$\begin{array}{l}\text { Journal of Thermal Analysis } \\
\quad \text { and Calorimetry }\end{array}$ & 0 & 11 & 11 \\
$\begin{array}{l}\text { International Journal of High } \\
\quad \text { Dilution Research }\end{array}$ & 0 & 7 & 7 \\
$\begin{array}{l}\text { Journal of Molecular Liquids } \\
\text { Annales Homéopathiques } \\
\quad \text { Françaises }\end{array}$ & 0 & 7 & 7 \\
\hline
\end{tabular}

different with Italy (26\% of publications), India (22\%), and Germany (14\%) appearing most active in the field in recent years (Fig. 5).

\section{Techniques}

A variety of experimental techniques have been used to investigate homeopathic dilutions. The experimental techniques were categorized in 11 categories: Electrical impedance (which included dielectric constant, dielectric relaxation, resistance, capacity, and impedance), Analytical methods (Inductively Coupled Plasma-Mass Spectrometry, Atomic Absorptions, radioactive tracers, and neutron activation), Spectroscopy (Ultra-Violet, Visible, Infra-Red, and FourierTransform Infra-Red), NMR (NMR spectroscopy and NMR relaxation times), Imaging methods (Kirlian photography, Xrays, photography, microscopy, crystallization, Transmission electron microscopy, Calorimetry, Electrochemistry (including $\mathrm{pH}$ measurements), Luminescence (fluorescence and thermoluminescence), Chromatography (including thin layer chromatography), Raman spectroscopy, Various physical (any other technique that did not fit another category).

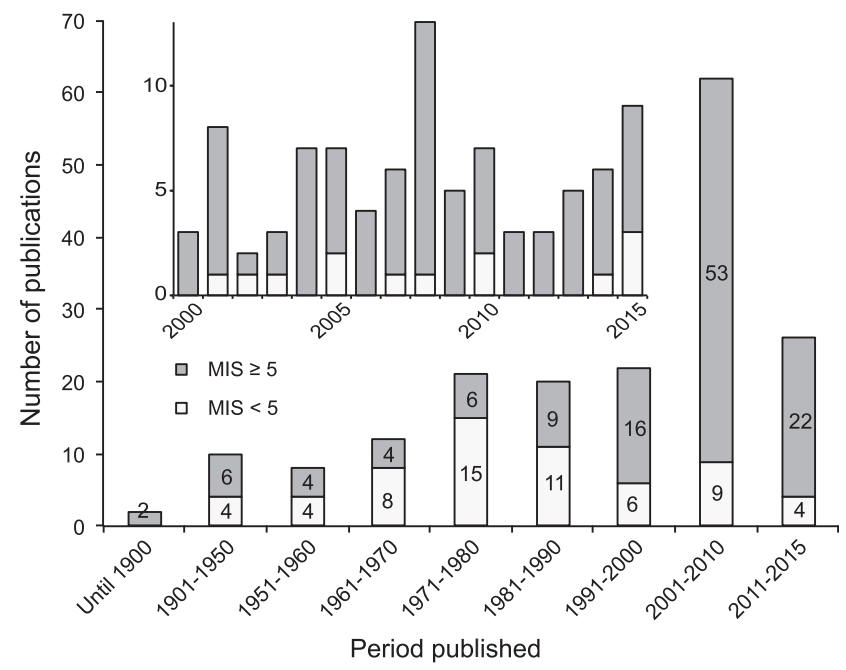

FIG. 2. Publications of physicochemical studies of homeopathic preparations per time period. MIS, Manuscript Information Score.

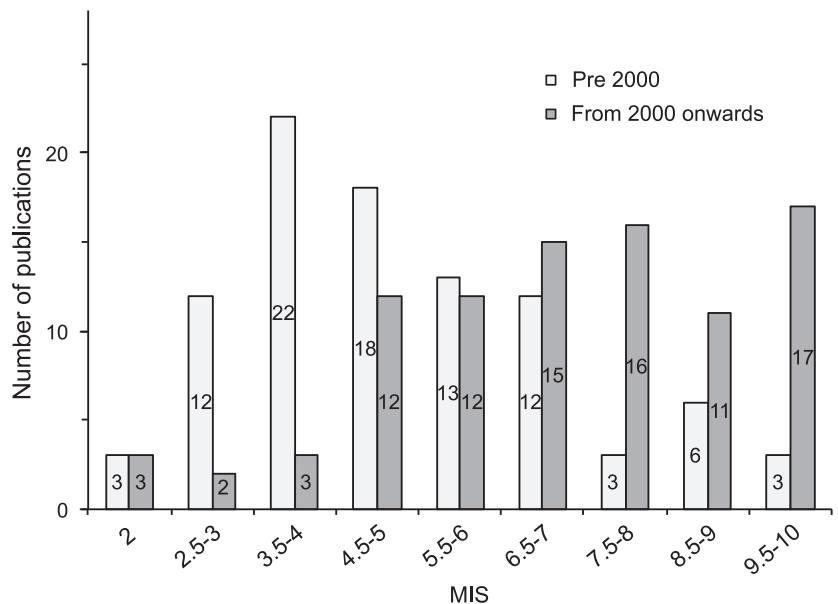

FIG. 3. Distribution of Manuscript Information Scores (MIS) (average of two scorings from two reviewers) for the publications before 2000 and from 2000 onward.

The breakdown of the number of publications per investigation technique used is shown in Figure 6. One paper may present experiments using several techniques. Techniques most commonly used were electrical impedance with 48 publications using this technique (26\% of publications), analytical methods (37 publications-20\%), spectroscopy (37 publications-20\%), and NMR (34 publications-19\%).

The picture, which emerges in terms of techniques used from 2000 onward, is very similar (data not shown). If one looks more closely at the geographical breakdown of investigative techniques from 2000 onward (data not shown),

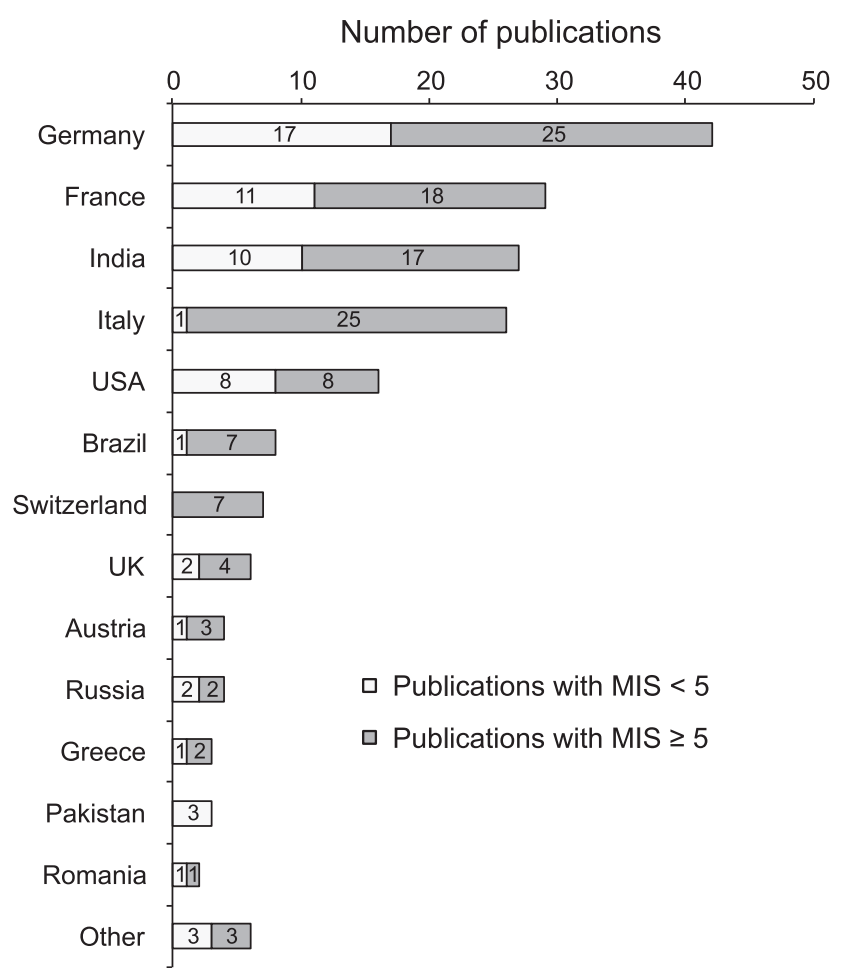

FIG. 4. Number of publications per country for all 183 publications. MIS, Manuscript Information Score. 


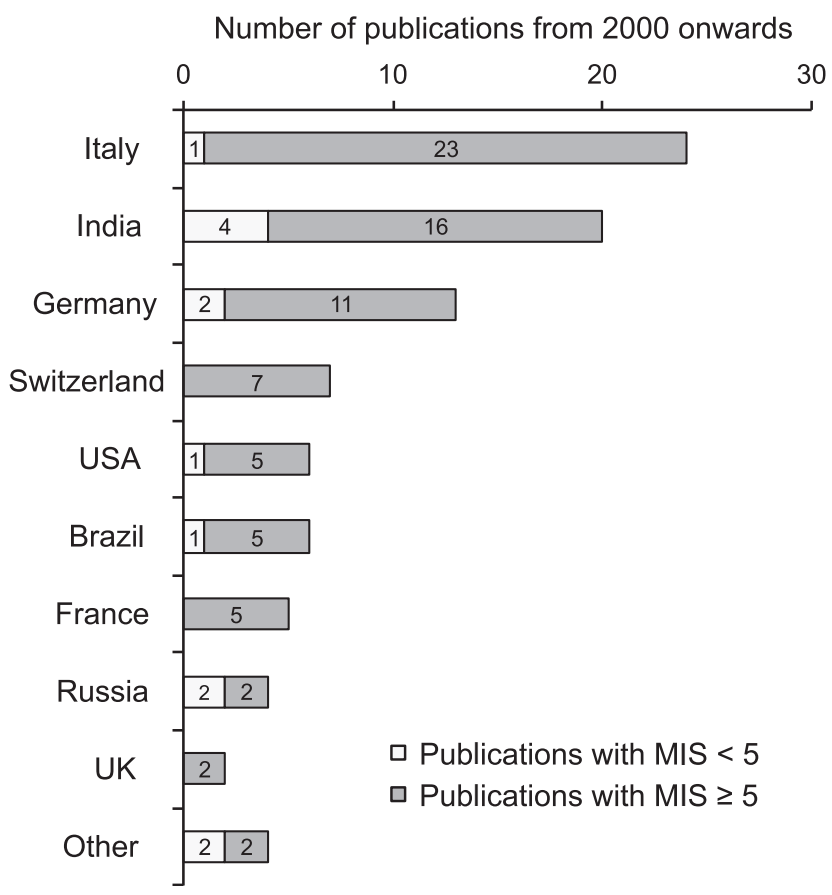

FIG. 5. Number of publications per country from 2000 onward. MIS, Manuscript Information Score.

we observe that certain countries weigh heavily in certain techniques. Italy accounts for $100 \%$ of calorimetry experiments, $69 \%$ of electrical impedance experiments, and 57\% of use of analytical techniques, whereas most spectroscopy experiments were performed in India (35\%) and Switzerland (24\%). Finally most NMR experiments were performed in

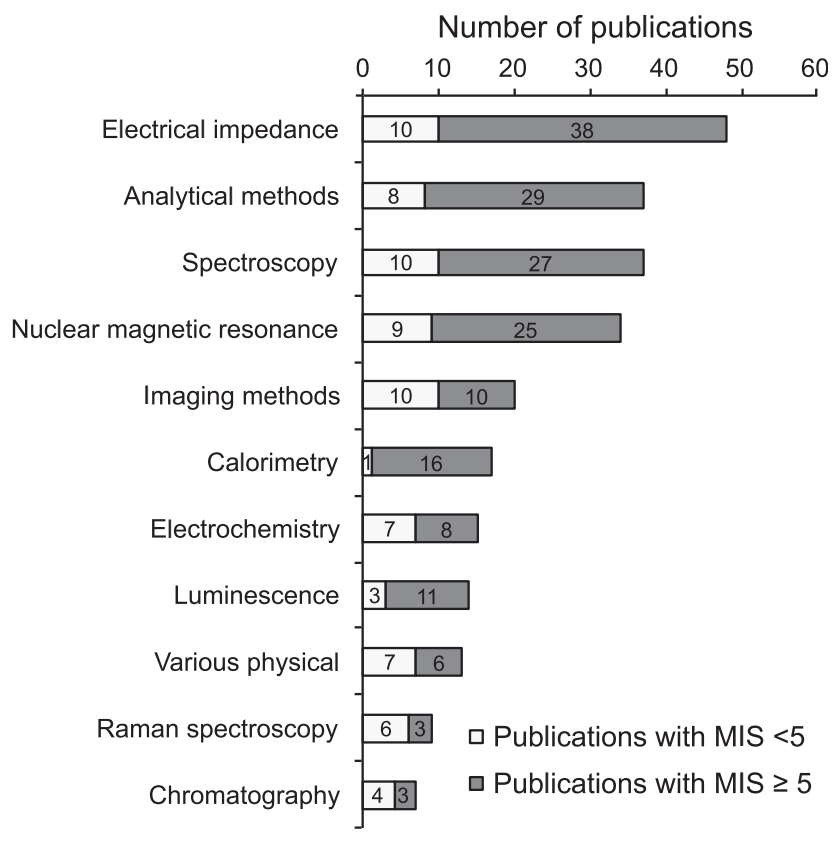

FIG. 6. Breakdown of publications in terms of investigative technique used (see text for more detailed description of what each category included). One publication can report on more than one technique. MIS, Manuscript Information Score.
France (33\%) and India (27\%). This shows the "hotspots" in physicochemical homeopathic research from 2000 onward.

\section{Discussion \\ Overview}

Our investigation identified 183 publications in physicochemical research of homeopathic preparations, starting with a first German publication in $1842 .{ }^{158}$ Of these 183 publications, $122(66 \%)$ had an MIS $\geq 5$ reflecting acceptable reporting quality. The number of publication per year has risen over time with a marked increase around 2000, leading to $50 \%$ of publications appearing from 2000 onward. Over $63 \%$ of publications were peer reviewed $(73 \%$ for publications with MIS $\geq 5$ ).

\section{Previous reviews and search strategy}

Becker-Witt et al. published a previous review in 2003 , which focused on the quality of physical research in homeopathy. ${ }^{27}$ They included investigations using measurements of dielectric strength, NMR, and spectroscopy (UV, Vis and IR), and explicitly excluded techniques such as refractometry, microcalorimetry, surface tension, conductivity, densitometry, and many others. They consulted MEDLINE, EMBASE, Current Contents, and the Karl and Veronica Carstens Foundation. Their search strategy yielded 44 publications with only 6 publications (14\%) being considered of high quality (Score for Assessment of Physical Experiments on Homeopathy [SAPEH] score $>7$ ). Our search strategy was wider, including areas that had been excluded from the Becker-Witt study. For comparison, we found 95 publications before 2000, 12 of which (13\%) have an MIS $\geq 7.5$ (equivalent to "high quality"). One further explanation for the higher number of publications in our review could also be our use of the specialized HomBRex database of basic research in homeopathy, which was not available at the time of the Becker-Witt literature search. ${ }^{210}$

Indeed, many of the old publications are not referenced in modern databases (e.g., Web of Science); so we had to rely on specialized databases such as the HomBRex database. ${ }^{210}$ Because of this lack of referencing of older publications, it is possible we missed some older references. In principle, this could only be resolved by manual scanning of older journals, which was beyond the scope of this review. Nonpublished investigations were also out of scope for this review.

\section{Quality assessment}

Becker-Witt et al. introduced the so-called SAPEH score in their 2003 review. ${ }^{27}$ This score is based on three fundamental quality constructs: methodology, experiment standardization, and presentation. The SAPEH score was designed to assess overall study quality.

In our review, we decided to restrict the quality assessment to "reporting quality" in five fields of particular interest for physicochemical investigations of homeopathic preparations: experimental procedure, materials, measuring instruments, potentization procedure, and controls (Table 1). The idea of this procedure is to include only publications in a more detailed qualitative evaluation that reported enough experimental details for the reviewers to understand what was actually done in the study presented. Any judgment 
whether the study design used was meaningful, whether the controls used were adequate, and whether any conclusions were justified compared to the data presented was postponed to the detailed qualitative evaluation.

The MIS design was also inspired by the prepublication checklist put together by Stock-Schröer in 2015 in the Reporting Experiments in Homeopathic Basic Research (REHBaR) scheme. ${ }^{211}$ However, the REHBaR scheme is a publication guideline for proper presentation of the work and not a tool to evaluate quality or methodological aspects.

A 2015 review by Schulte and Endler carried on the work of Becker-Witt, investigating the quality of publications using experimental methods in ultra-high dilutions, 2004-2014. ${ }^{24}$ They analyzed nine publications published in the journal Homeopathy. Overall quality of the nine papers analyzed was low (one publication with SAPEH = 5). Our analysis did not include any restriction on the journal where the findings were published. We found, in contrast, 66 publications over the same period, 2004-2014, 59 of which had an MIS $\geq 5$. A quick look at these publications reveals that the majority were indeed not published in the journal Homeopathy. Accordingly, our conclusions are somewhat different than Schulte's: where Schulte reports that studies in the field have been appearing at a steady rate, we find a marked increase from 2000 onward, the majority of which was not published in the journal Homeopathy and hence was not analyzed by Schulte. Also, the rather low incidence of high-quality publications reported is not reflected in our findings where we see a significant increase in quality from 2000 onward, with 44 (48\%) publications having an MIS $\geq 7.5$, corresponding to "high reporting quality."

\section{Geographic distribution}

With its long history in homeopathy, Europe currently dominates, in terms of number of publications, with 115 publications (63\%), with Germany leading with 42 publications (23\%) followed by France with 29 publications (16\%), and Italy with 26 publications (14\%). Coming in second place overall, we have India with 27 publications (15\%).

This European dominance has decreased slightly in recent years with 53 publications (58\%) from 2000 onward (Fig. 5). This can be attributed mostly to the strong appearance of Indian research over the last few years with 20 publications (22\%) from 2000 onward versus 7 (8\%) before 2000. Similarly, we notice that most of Italy's publications appeared in the last few years with 24 publications (26\%) appearing from 2000 onward versus $2(2 \%)$ before 2000.

The 2014 review by Clausen et al., ${ }^{28}$ which also included in vitro and in vivo experiments, reported on 1,383 publications. They found the main countries publishing in this field to be France with 267 publications (14\%), Germany with 246 publications (13\%), and India with 237 publications $(13 \%)$.

\section{Conclusions}

We found 183 publications reporting physicochemical experiments investigating homeopathic dilutions. The rate of publication in the field has increased from $\sim 2$ per year from the 1970s until 2000 to over 5.5 publications per year since then. The reporting quality of the studies has increased over the years with a significant increase from $13 \%$ of publications rated as "high reporting quality" before 2000 compared to $48 \%$ since then. Europe is leading in terms of total number of publications, Germany (23\% of publications) leading in front of France (16\%) and Italy (14\%). India has been making steady progress in the field in recent years (15\%). The most frequently used techniques were electrical impedance (used in $26 \%$ of publications), analytical methods, spectroscopy, and NMR techniques ( $\sim 20 \%$ each).

\section{Acknowledgments}

We thank the Karl and Veronica Carstens Foundation and DHU library for providing us full-text references.

\section{Author Disclosure Statement}

S.W. is an employee of Hevert-Arzneimittel, Germany; however, none of the publications included in this review used Hevert products.

\section{References}

1. Frass M, Strassl RP, Friehs H, et al. Use and acceptance of complementary and alternative medicine among the general population and medical personnel: A systematic review. Ochsner J 2012;12:45-56.

2. Ghosh AK. A short history of the development of homeopathy in India. Homeopathy 2010;99:130-136.

3. Srinivasan R, Sugumar VR. Spread of traditional medicines in India: Results of national sample survey organization's perception survey on use of Ayush. J Evid Based Complementary Altern Med 2015;pii:2156587215607673.

4. Dossett ML, Davis RB, Kaptchuk TJ, Yeh GY. Homeopathy use by US adults: Results of a national survey. Am J Public Health 2016;106:743-745.

5. Jäger T, Scherr C, Shah D, et al. Use of homeopathic preparations in experimental studies with abiotically stressed plants. Homeopathy 2011;100:275-287.

6. Betti L, Trebbi G, Majewsky V, et al. Use of homeopathic preparations in phytopathological models and in field trials: A critical review. Homeopathy 2009;98:244-266.

7. Majewsky V, Arlt S, Shah D, et al. Use of homeopathic preparations in experimental studies with healthy plants. Homeopathy 2009;98:228-243.

8. Bonamin LV, Cardoso TN, de Carvalho AC, Amaral JG. The use of animal models in homeopathic research-a review of 2010-2014 PubMed indexed papers. Homeopathy 2015;104:283-291.

9. Mathie RT, Lloyd SM, Legg LA, et al. Randomised placebo-controlled trials of individualised homeopathic treatment: Systematic review and meta-analysis. Syst Rev 2014;3:142.

10. Mathie RT, Ramparsad N, Legg LA, et al. Randomised, double-blind, placebo-controlled trials of non-individualised homeopathic treatment: Systematic review and metaanalysis. Syst Rev 2017;6:63.

11. Chikramane PS, Suresh AK, Bellare JR, Kane SG. Extreme homeopathic dilutions retain starting materials: A nanoparticulate perspective. Homeopathy 2010;99: 231-242.

12. Chikramane PS, Kalita D, Suresh AK, et al. Why extreme dilutions reach non-zero asymptotes: A nanoparticulate hypothesis based on froth flotation. Langmuir 2012;28: 15864-15875. 
13. Temgire MK, Suresh AK, Kane SG, Bellare JR. Establishing the interfacial nano-structure and elemental composition of homeopathic medicines based on inorganic salts: A scientific approach. Homeopathy 2016;105:160-172.

14. Anick DJ. The octave potencies convention: A mathematical model of dilution and succussion. Homeopathy 2007;96:202-208.

15. Anick DJ, Ives JA. The silica hypothesis for homeopathy: Physical chemistry. Homeopathy 2007;96:189-195.

16. Demangeat J-L. NMR relaxation evidence for soluteinduced nanosized superstructures in ultramolecular aqueous dilutions of silica-lactose. J Mol Liquids 2010;155:71-79.

17. Kratky K. [Homeopathy and structure of water: A physical model]. Forschende Komplementarmed Klass Naturheilkd 2004;11:24-32. (Article in German).

18. Bell IR, Schwartz GE. Enhancement of adaptive biological effects by nanotechnology preparation methods in homeopathic medicines. Homeopathy 2015;104:123-138.

19. Waisse S, Bonamin LV. Explanatory models for homeopathy: From the vital force to the current paradigm. Homeopathy 2016;105:280-285.

20. Walach H. [Entanglement model of homeopathy as an example of generalized entanglement predicted by weak quantum theory]. Forschende Komplementarmed Klass Naturheilkd 2003;10:192-200 (Article in German).

21. Weingärtner $\mathrm{O}$. The homeopathic mechanism from the viewpoint of a quantum mechanical paradoxon. J Altern Complement Med 2005;11:773-774.

22. Beauvais F. Memory of water and blinding. Homeopathy 2008;97:41-42.

23. Milgrom LR. A new geometrical description of entanglement and the curative homeopathic process. J Altern Complement Med 2008;14:329-339.

24. Schulte J, Endler PC. Update on preliminary elements of a theory of ultra high dilutions. Homeopathy $2015 ; 104$ : 337-342.

25. Bellavite P, Marzotto M, Olioso D, et al. High-dilution effects revisited. 1. Physicochemical aspects. Homeopathy 2014;103:4-21.

26. Schulte J, Endler PC. Outline of experimental physical methods to investigate specific structures of ultra highly diluted solvents. In: Endler PC, Schulte J, eds. Ultra High Dilution. Dordrecht, the Netherlands: Springer Netherlands, 1994:99-104. https://link.springer.com/book/10.1007/97894-015-8342-8\#about

27. Becker-Witt C, Weisshuhn TER, Lüdtke R, Willich SN. Quality assessment of physical research in homeopathy. J Altern Complement Med 2003;9:113-132.

28. Clausen J, van Wijk R, Albrecht H. Geographical and temporal distribution of basic research experiments in homeopathy. Homeopathy 2014;103:193-197.

29. PRISMA. Online document at: http://prisma-statement.org. Accessed April 3, 2017.

30. Aabel S, Fossheim S, Rise F. Nuclear magnetic resonance (NMR) studies of homeopathic solutions. Br Homeopath J 2001;90:14-20.

31. Anagnostatos GS, Pisses P, Viras K, Provata M. Physicochemical study of homeopathic dilutions. In: Bornoroni C, ed. Omeomed 92. First International Congress, 1992. Urbino, Italy: Compositori.

32. Anagnostatos GS, Pissis P, Viras K. Possible water cluster formation by dilution and succussions. In: Anagnostatos GS, von Oertzen W, eds. Atomic and Nuclear Clusters. Berlin, Germany: Springer, 1995:215-217.
33. Anagnostatos GS, Pissis P, Viras K, Soutzidou M. Theory and experiments on high dilutions. In: Ernst E, Hahn EG, eds. Homoeopathy-A Critical Appraisal. Oxford, United Kingdom: Butterworth-Heinemann, 1998:153-166.

34. Anick DJ. High sensitivity 1H-NMR spectroscopy of homeopathic remedies made in water. BMC Complement Altern Med 2004;4:15.

35. Assumpcao R. Electrical impedance and HV plasma images of high dilutions of sodium chloride. Homeopathy 2008;97:129-133.

36. Bardet L, Luu C, Luu DV. Etude des dilutions homéopathiques par effet Raman-Laser. Travaux de la Société de Pharmacie de Montpellier 1975;35:361-372.

37. Baumgartner S, Wolf M, Skrabal P, et al. High-field ${ }^{1} \mathrm{H} \mathrm{T}_{1}$ and $\mathrm{T}_{2}$ NMR relaxation time measurements of $\mathrm{H}_{2} \mathrm{O}$ in homeopathic preparations of quartz, sulfur, and copper sulfate. Naturwissenschaften 2009;96:1079-1089.

38. Beier K. Über physikalische Wirkungen oder Eigenschaften echter homöopathischer Hochpotenzen. Leipzig, Germany: Universität Leipzig, Med. Fakultät, 1953.

39. Bell IR, Lewis DA, Brooks AJ, et al. Gas discharge visualization evaluation of ultramolecular doses of homeopathic medicines under blinded, controlled conditions. J Altern Complement Med 2003;9:25-38.

40. Bell IR, Muralidharan S, Schwartz GE. Nanoparticle characterization of traditional homeopathically-manufactured Gelsemium sempervirens medicines and placebo controls. Nanomed Biotherapeut Discov 2015;5:136.

41. Bell IR, Muralidharan S, Schwartz GE. Nanoparticle characterization of traditional homeopathically-manufactured silver (argentum metallicum) medicines and placebo controls. Nanomed Nanotechnol 2015;6:311.

42. Belon P, Elia V, Elia L, et al. Conductometric and calorimetric studies of the serially diluted and agitated solutions-on the combined anomalous effect of time and volume parameters. J Therm Anal Calorim 2008;93: 459-469.

43. Betti L, Elia V, Napoli E, et al. Biological effects and physico-chemical properties of extremely diluted aqueous solutions as a function of aging-time. Front Life Sci 2011; $5: 117-126$.

44. Bhattacharyya SS, Mandal SK, Biswas R, et al. In vitro studies demonstrate anticancer activity of an alkaloid of the plant Gelsemium sempervirens. Exp Biol Med 2008; 233:1591-1601.

45. Boericke GW, Smith RB. Modern aspects of homeopathic research. J Am Inst Homeopath 1963;56:363-366.

46. Boericke GW, Smith RB. Modern aspects of homeopathic research (continued). J Am Inst Homeopath 1965; 58:158-167.

47. Boiron J. Kontrolle der homöopathischen Kügelchen mit Hilfe markierter Präparationen. ZKH 1963;7:241-248.

48. Boiron J. Nouvellle technique de préparation des dilutions korsakowiennes. Ann Homéopathiques Françaises 1965;7: 586-594.

49. Boiron J, Vinh CLD. Contribution to the study of the physical structure of homoeopathic dilutions by Raman laser effect. In: Intérêt d'adhérer à la LMHI, ed. 31e Congres de la Ligue Médicale Homéopathique Internationale Athens, Greece, 17.05.1976-22.05.1976. Athens, Greece: Eigenverlag, 1976:459-474.

50. Bonet-Maury P, Deysine A, Vogeli L-M. Etude de dilutions homéopathiques par les radio-isotopes. Ann Pharm Franc 1954;12:654-663. 
51. Botha I, Ross AHA. A nuclear magnetic resonance spectroscopy comparison of $3 \mathrm{C}$ trituration derived and 4C trituration derived remedies. Homeopathy 2008;97: 196-201.

52. Boyd WE. Research on the Low Potencies of Homoeopathy, an Account of Some Physical Properties Indicating Activity. London, United Kingdom: Heinemann, 1936.

53. Brucato A, Stephenson J. The photometric determination of the concentration of homoeopathic dilutions of mercuric sulfide (HgS). J Am Inst Homeopath 1957;50:242-243, 253.

54. Brucato A, Stephenson J. Dielectric strength testing of homeopathic dilutions of $\mathrm{HgCl}_{2}$. J Am Inst Homeopath 1966;59:281-286.

55. Cacace CM, Elia L, Elia V, et al. Conductometric and $\mathrm{pH}$ metric titrations of extremely diluted solutions using $\mathrm{HCl}$ solutions as titrant A molecular model. J Mol Liquids 2009;146:122-126.

56. Cartwright SJ. Solvatochromic dyes detect the presence of homeopathic potencies. Homeopathy 2016;105:55-65.

57. Chakraborty I, Datta S, Sukul A, et al. Variation in free and bound water molecules in different homeopathic potencies as revealed by their fourier transform infrared spectroscopy (FTIR). Int J High Dilution Res 2014;13: 189-196.

58. Chibici-Revneanu C. UV-spektroskopische und dielektrische Untersuchungen von Wasser und hoch verdünnten homöopathischen Arzneistofflösungen. Leipzig, Germany: Universität Leipzig, Fakultät f. Biowissenschaften, Pharmazie und Psychologie (Institut für Pharmazie), 2005.

59. Ciavatta L, Elia V, Napoli E, Niccoli M. New physicochemical properties of extremely diluted solutions. Electromotive force measurements of galvanic cells sensible to the activity of $\mathrm{NaCl}$ at $25^{\circ} \mathrm{C}$. J Solution Chem 2008;37: 1037-1049.

60. Conte RR, Berliocchi H, Lasne Y, Vernot G. Theory of High Dilutions and Experimental Aspects. Paris, France: Polytechnica, 1996.

61. Datta DD, Bose PC, Ghosh D. Spectrophotometric estimation of elemental sulphur in homoeopathic sulphur mother tincture and $4 \times$ dilution. J Am Inst Homeopath 1972;65:53-55.

62. Daudel P, Robilliart M. Étude des dilutions homéopathiques a l'aide de la méthode des indicateurs radioactifs. Cahiers d'homéopathie et de thérapeutique comparée 1946;12:153-157.

63. de Alvarenga ES, de Oliveira APM, da Silva RTB, Casali VWD. Effect of magnesium phosphoricum $12 \mathrm{C}$ on sodium dodecylsulphate by $13 \mathrm{C}$ nuclear magnetic resonance. Int $\mathrm{J}$ High Dilution Res 2009;8:3-8.

64. Demangeat J-L. NMR water proton relaxation in unheated and heated ultrahigh aqueous dilutions of histamine: Evidence for an air-dependent supramolecular organization of water. J Mol Liquids 2009;144:32-39.

65. Demangeat J-L. Nanosized solvent superstructures in ultramolecular aqueous dilutions: Twenty years' research using water proton NMR relaxation. Homeopathy 2013; 102:87-105.

66. Demangeat JL. Gas nanobubbles and aqueous nanostructures: The crucial role of dynamization. Homeopathy 2015;104:101-115.

67. Demangeat JL, Demangeat C, Gries P, et al. Modifications des temps de relaxation RMN à $4 \mathrm{MHz}$ des protons du solvant dans les très hautes dilution salines de silice/lactose. J Méd Nucl Biophys 1992;16:135-145.
68. Demangeat JL, Gries P, Poitevin B. Modification of $4 \mathrm{MHz} \mathrm{NMR}$ water proton relaxation times in highly diluted aqueous solutions. Br Homeopath J 1995;84: 169-170.

69. Demangeat JL, Gries P, Poitevin B. Modification of $4 \mathrm{MHz}$ N.M.R. water proton relaxation times in very high diluted aqueous solutions. In: Bastide M, ed. Signals and Images. Dordrecht, Netherland: Kluwer Academic, 1997: 95-110.

70. Demangeat JL, Gries P, Poitevin B, et al. Low-field NMR water proton longitudinal relaxation in ultrahighly diluted aqueous solutions of silica-lactose prepared in glass material for pharmaceutical use. Appl Magn Reson 2004;26:465-481.

71. Dragan G. Some consideration of coherency in topoenergetic terms, I. High-resolution mixing calorimetry (HRMC) experiments on aqueous solutions. J Therm Anal 1992;38: 1497-1508.

72. Ducassou P. Expérimentations en cours sur l'appareil à dynamisations korsakoviennes. Ann Hom Franc 1973;15: 129-140.

73. Elia V, Ausanio G, Gentile FS, et al. Experimental evidence of stable water nanostructures in extremely dilute solutions, at standard pressure and temperature. Homeopathy 2014;103:44-50.

74. Elia V, Baiano S, Duro I, et al. Permanent physicochemical properties of extremely diluted aqueous solutions of homeopathic medicines. Homeopathy 2004;93: 144-150.

75. Elia V, Elia L, Cacace P, et al. 'Extremely diluted solutions' as multi-variable systems - a study of calorimetric and conductometric behaviour as a function of the parameter time. J Therm Anal Calorim 2006;84:317-323.

76. Elia V, Elia L, Marchese M, et al. Interaction of "extremely diluted solutions" with aqueous solutions of hydrochloric acid and sodium hydroxide - a calorimetric study at $298 \mathrm{~K}$. J Mol Liquids 2007;130:15-20.

77. Elia V, Elia L, Marchettini N, et al. Physico-chemical properties of aqueous extremely diluted solutions in relation to ageing. J Therm Anal Calorim 2008;93:10031011.

78. Elia V, Elia L, Montanino M, et al. Conductometric studies of the serially diluted and agitated solutions on an anomalous effect that depends on the dilution process. J Mol Liquids 2007;135:158-165.

79. Elia V, Elia L, Napoli E, Niccoli M. Conductometric and calorimetric studies of serially diluted and agitated solutions: The dependence of intensive parameters on volume. Int J Ecodyn 2006;1:361-372.

80. Elia V, Marchese M, Montanino M, et al. Hydrohysteretic phenomena of "extremely diluted solutions" induced by mechanical treatments: A calorimetric and conductometric study at $25^{\circ} \mathrm{C}$. J Solution Chem 2005;34:947-960.

81. Elia V, Marchettini N, Napoli E, Niccoli M. The role of ethanol in extremely diluted solutions. J Therm Anal Calorim 2014;116:477-483.

82. Elia V, Marrari LA, Napoli E. Aqueous nanostructures in water induced by electromagnetic fields emitted by EDS: A conductometric study of fullerene and carbon nanotube EDS. J Therm Anal Calorim 2012;107:843-851.

83. Elia V, Napoli E. Dissipative structures in extremely diluted solutions of homeopathic medicines: A molecular model based on physico-chemical and gravimetric evidences. Int J Des Nat Ecodyn 2010;5:39-48. 
84. Elia V, Napoli E, Niccoli M. On the stability of extremely diluted aqueous solutions at high ionic strength-a calorimetric study at 298 K. J Therm Anal Calorim 2008; 92:643-648.

85. Elia V, Napoli E, Niccoli M. A molecular model of interaction between extremely diluted solutions and $\mathrm{NaOH}$ solutions used as titrant. Conductometric and pHmetric titrations. J Mol Liquids 2009;148:45-50.

86. Elia V, Napoli E, Niccoli M. Thermodynamic parameters for the binding process of the $\mathrm{OH}$-ion with the dissipative structures. Calorimetric and conductometric titrations. J Therm Anal Calorim 2010;102:1111-1118.

87. Elia V, Napoli E, Niccoli M. On the stability of extremely diluted solutions to temperature. $\mathrm{J}$ Therm Anal Calorim 2013;113:963-970.

88. Elia V, Napoli E, Niccoli M, et al. New physico-chemical properties of extremely dilute solutions. A conductivity study at $25^{\circ} \mathrm{C}$ in relation to ageing. J Solution Chem 2008; 37:85-96.

89. Elia V, Napoli E, Niccoli M, et al. New physico-chemical properties of extremely diluted aqueous solution-a calorimetric and conductivity study at $25^{\circ} \mathrm{C}$. J Therm Anal Calorim 2004;78:331-342.

90. Elia V, Niccoli M. Thermodynamics of extremely diluted aqueous solutions. Ann N Y Acad Sci 1999;827: 241-248.

91. Elia V, Niccoli M. New physico-chemical properties of water induced by mechanical treatments. A calorimetric study at $25^{\circ} \mathrm{C}$. J Therm Anal Calorim 2000;61: 527-537.

92. Elia V, Niccoli M. New physico-chemical properties of extremely diluted aqueous solutions. J Therm Anal Calorim 2004;75:815-836.

93. Frisse R. Adsorptionsuntersuchung und Neutronenaktivierungsanalyse homöopathischer Dilutionen. Bonn, Germany: Hohe Mathematisch-Naturwissenschaftliche Fakultät, Rheinische Friedrich-Wilhelms-Universität; 1981.

94. Gangar HU. Management and control of genetic processes in cotton plants through homoeopathy. Ind J Res Hom 2007;1:1-5.

95. Gautam RS, Tewari KP, Roper NK, Mishra RK. Spectrophotometric analysis of potentisation of Euphrasia officinalis. Hahnemann Gleanings 1977;44:1-5.

96. Gay A. Présence d'un facteur physique dans les dilutions homéopathiques. Lyon, France: Editions des Laboratoires P.H.R., 1951.

97. Gebhardt A. FTIR-spektroskopische Untersuchungen an wässrigen und ethanolischen homöopathischen Arzneimitteln. Leipzig, Germany: Fakultät für Biowissenschaften, Pharmazie und Psychologie, 2002.

98. Gorlowska K, Gorlowska J, Skibinski R, Komsta L. Chemometrics meets homeopathy - an exploratory analysis of infrared spectra of homeopathic granules. J Pharmaceut Biomed Anal 2015;115:36-38.

99. Güldenstern W. Fluoreszenzmessungen des Präparates Aesculus Cortex und des Wirkstoffes Aesculinum. Der Merkurstab 2001;54:307-312.

100. Hadley SJ. An experiment showing an increase with dilution in a physical parameter. Br Hom J 1981;70:129_ 135.

101. Hartmann E, Farenkopf R. Über eine neue Möglichkeit, Hochpotenzen physikalisch-meßtechnisch zu erfassen. AHZ 1952;197:127-129.
102. Hartmann E, Götz J, Langer FK. Kann ein homöopathisches Präparat elektrophysikalisch meßbare Veränderungen an destilliertem Wasser erzielen? EHK 1992; 41:559-564.

103. Heintz E. Physikalische Wirkungen hochverdünnter potenzierter Substanzen. Die Naturwissenschaften 1941;48: 713-725.

104. Heintz E. Bemerkungen zu meinem Artikel: Physikalische Wirkungen hochverdünnter, potenzierter Substanzen. Naturwiss 1942;30:642.

105. Heintz E. Eine neuartige Anordnung zum Messen physikalisch-chemischer Wirkungen von Potenzen: Das D-Element. Elemente der Naturwissenschaft 1971;15:33-44.

106. Heintz E. [New experiences of the mode of action of serial dilutions]. Ann Hom Franc 1971;13:515-530 (Article in French).

107. Heintz E. [Measurement of the action of serial dilutions by means of electric elements]. Ann Hom Franc 1972;14: 275-284 (Article in French).

108. Holandino C, Harduim R, da Veiga VF, et al. Modeling physical-chemical properties of high dilutions. An electrical conductivity study. Int J High Dilution Res 2008;7: $165-173$.

109. Holandino C, Leal FD, de Olivereira Barcellos B, et al. Chapter 3: Mechanical versus handmade succussions, a physical chemistry comparison. In: Bonamin LV, ed. Signals and Images. Contributions and Contradictions About High Dilution Research. New York: Springer, 2008:37-48.

110. Hsu Y-C, Liang Y-S, Cheng P-Y. A study of water crystal growing based on dilution and succussion theory of homeopathy. In: Wei PS, ed. Machine Design and Manufacturing Engineering III 2014:61-64.

111. Hüttenrauch R, Fricke S. Molekulargalenische Bewertung der konventionellen Feststoffverarbeitung in der Homöopathie. Pharmazie 1985;40:129-130.

112. Ives G. Relative permittivity as a measure of homoeopathic potency effect, negative results on repeating previous work. Midlands Hom Res Group Commun 1980;3:15-16.

113. Jerman I, Berden M, Škarja M. Instrumental measurements of different homeopathic dilutions of potassium iodide in water. Acupunct Electrother Res 1999;24:29-44.

114. Jussal RL. A brief report from the research directorate. Homoeopathician 1978;2:78-82.

115. Jussal RL, Meera S, Dua RD, Mishra RK. Physical effects on the suspending mediums by compounds in asymptomically infinite dilutions. Hahnemann Glean 1982;94:114-120.

116. Jussal RL, Mishra RK, Dua RD. Dielectric dispersion of weak alkoholic solutions of some drugs at high frequencies using time domain spectroscopy. Hahnemann Glean 1983;50:358-366.

117. Kar S, Bandyopadhyay P, Chakraborty S, et al. Derivation of an empirical relation between the size of the nanoparticle and the potency of homeopathic medicines. Int $\mathbf{J}$ High Dilution Res 2015;14:2-7.

118. Khan MT. Comparison between preparation of aconite napellus potencies made by two different homeopathic chemists by means of spectroscopic method. Proceedings of the International Homeopathic Medical Organization (OMHI) Congress. Mexico, 1980.

119. Khan MT, Mriphh MCS, Akber MN. Determination of plumbum in the low and high homoeopathic potencies by means of eel atomic absorption spectrophotometer. In: LMHI, ed. 32nd International Homeopathic Medical Con- 
gress of the International Homoeopathic Medical League, New Delhi, India, October 5-11, 1977:126-129.

120. Khan MT, Saify Z. Estimation of low and higher homoeopathic potencies by means of biochemical and pharmacological methods, second research report. J Am Inst Homeopath 1975;68:97-104.

121. Kirn. Experimentelle Versuche über die physikalischen Eigenschaften homöopathischer Potenzen. AHZ 1911; 159:15-25.

122. Klein SD, Sandig A, Baumgartner S, Wolf U. Differences in median ultraviolet light transmissions of serial homeopathic dilutions of copper sulfate, Hypericum perforatum, and sulfur. Evid Based Complement Altern Med 2013;Article ID: 370609, 2013.

123. Klein SD, Wolf U. Investigating homeopathic verum and placebo globules with UV spectroscopy. Forsch Komplementarmed 2013;20:295-297.

124. Knapp D. Die Sichtbarmachung von Energiemustern bei homöopathischen Potenzen. In: Weingärtner O, ed. Forschung zum Nachweis von Wirkung und Wirksamkeit homöopathischer Arzneimittel. Heidelberg, Germany: Haug, 1984:62-102.

125. Knapp D. Die bioenergetische Strahlung und homöopathische Medikamente. Erfahrungsheilkunde 1985;2: 74-82.

126. Knauer H. Nachweis der Wirkung potenzierter Lösungen auf chemisch-physikalischem Wege. Acta Hom 1969;13: 157-164.

127. Knauer H. Beiträge zur Potenzforschung Pforzheim, 1970.

128. Knauer H. Beiträge zur Potenzforschung, Versuche zur Potenzierung nach der Ein- und Mehrgefäßmethode; Über die Haltbarkeit potenzierter Lösungen. Acta Hom 1971; 15:143-148.

129. Kolisko L. Physiologischer und physikalischer Nachweis der Wirksamkeit kleinster Entitäten. Stuttgart, Germany: Der Kommende Tag AG, 1923.

130. Kolisko L. Physiologischer und physikalischer Nachweis der Wirksamkeit kleinster Entitäten (1923-1959). Stuttgart, Germany: Arbeitsgemeinschaft anthroposophischer Ärzte, 1959.

131. Kracmar F. Biophysik der homöopathischen Arzneiwirkung. AHZ 1966;211:481-500.

132. Kumar A, Jussal R. A hypothesis on the nature of homoeopathic potencies. Br Hom J 1979;68:197-204.

133. Lasne Y. Proprietés des solutions "homéopathiques", Mesure de la relaxation magnétiques T2. Lyon, France: Université Claude Bernard Lyon 1, U.E.R. Faculté de Pharmacie, 1986.

134. Lasne Y, Duplan JC, Fenet B, Guerin A. Contribution à l'approche scientifique de la doctrine homéopathique. De Natura Rerum 1989;3:38-43.

135. Lasne Y, Duplan JC, Mallet JJ. Mise en évidence de signaux physiques émanant de solutions dilutees-dynamisées ou "homéopathiques". Bull du M.TS (Medical Telematic System). 2. 1985 Lacenas, France:Centre Européen d'Informatique et d'Automation (CEIA). 2ème bulletin du MTS (Medical Telematic System).

136. Lechuga VRL, Martinez RER, Lopez LOM, Barajas NYG. Résultats des recherches de l'étude fluorométrique des médicaments homéopathiques. Homéopathie Francaise 1991;79:22-25.

137. Leeser O, Janner K. Untersuchungen über die Potenzierung in der Homöopathie mit Hilfe von radioaktivem Phosphor. Arch Hom 1953;1:9-17.
138. Lefebvre N, Aubin M, Ferret-Bouin Y, Vrignaud C. Etude de dilutions homéopathiques hahnémanniennes à l'aide du glucose marqué au carbone 14. Ann Hom Franc 1978;20:227-235.

139. Lenger K. Homeopathic potencies identified by a new magnetic resonance method: Homeopathy-an energetic medicine. Subtle Energ Energ Med 2004;15:225-243.

140. Lenger K, Bajpai RP, Drexel M. Delayed luminescence of high homeopathic potencies on sugar globuli. Homeopathy 2008;97:134-140.

141. Lenger K, Bajpai RP, Spielmann M. Identification of unknown homeopathic remedies by delayed luminescence. Cell Biochem Biophys 2014;68:321-334.

142. Lobyshev VI. Water is a sensor to weak forces including electromagnetic fields of low intensity. Electromagn Biol Med 2005;24:449-461.

143. Lobyshev VI, Tomkevich MS, Petrushanko IY. Experimental study of potentiated aqueous solutions. Biophysics 2005;50:416-420.

144. Lobyshev VI, Tomkevitch MS. Luminescence study of homeopathic remedies. In: Priezzhev AV, Cote GL (eds). Optical Diagnostics and Sensing of Biological Fluids and Glucose and Cholesterol Monitoring, Proceedings of the SPIE, Vol 4263. Russia: MAIK Navka/Interperiodica, 2001, pp 1605-7422.

145. Ludwig W. Physikalische Grundlagenforschung in Bezug auf Informationsspeicherung in lebenden Systemen und homöopathischen Medikamenten, Strukturierung von Wasser und Alkohol. EHK 1991;40:293-295.

146. Ludwig W. Spektroskopische Messungen an Resonanzhomöopathika. EHK 1998;47:335-338.

147. Ludwig W. Wissenschaftliche Grundlagen zur Wirkung homöopathischer Mittel. In: Würthle R, ed. Homöopathie für Garten- und Zimmerpflanzen. München, Germany: BLV Verlagsgesellschaft mbH, 2002:105-122.

148. Luu-d-Vinh C. Les dilutions homéopathiques, Contrôle et étude par spectrographie Raman-laser. Montpellier, France: Université de Montpellier, Faculté de Pharmacie et Institut Européen des Sciences Pharmaceutiques Industrielles, 1974.

149. Luu-d-Vinh C. Etude des dilutions homéopathique par effet Raman-Laser. Ann Homeopath Franc 1975;17:433444.

150. Maag GW. Untersuchung der Potenzen von Silbernitrat D1-D12 und D1-D33. Dt Z Hom 1932;49:277-285.

151. Maag GW. Untersuchungen über die Schüttelzeiten von Metallpotenzen. Dt Z Hom 1933;49:281-286.

152. Maag GW. Zusammenhang von Potenzreihen mit den Vorgängen am Sternenhimmel, Untersuchung von Silbernitrat D1 bis D33 zu den Zeiten der 4 Mondphasen. ZKH 1965;9:166-173.

153. Mahata CR. Dielectric dispersion studies of some potentised homeopathic medicines reveal structured vehicle. Homeopathy 2013;102:262-267.

154. Maier K. Spektroskopische Untersuchungen an potenzierten Proben des Präparates Aesculus Cortex. Der Merkurstab 2001;54:303-306.

155. Maity T, Ghosh D, Mahata CR. Effect of dielectric dispersion on potentised homeopathic medicines. Homeopathy 2010;99:99-103.

156. Marschner G. Bioelektronische Studien zum Verständnis des Wirkungsmechanismus homöopathischer Potenzen. Erfahrungsheilkunde 1985;2:83-91.

157. Marschollek B, Nelle M, Wolf M, et al. Effects of exposure to physical factors on homeopathic preparations 
as determined by ultraviolet light spectroscopy. ScientificWorldJournal 2010;10:49-61.

158. Mayrhofer C. Mikroskopische Untersuchungen der homöop. Metallpräparate, Durch Zeichnungen erläutert. Hygea 1842;16:17-35.

159. Mayrhofer C. Mikroskopische Untersuchungen der homöopathischen Metallpräparate, (Schluss vom vor. Hefte). Hygea 1842;16:97-106.

160. Mendez NM. Changes in physico-chemical parameters of homeopathic remedies ferrum metallicum $\mathrm{CH} 6$ and ferrum metallicum $\mathrm{CH} 30$ after exposure to high frequency electromagnetic radiation of low intensity. Radiats Biol Radioekol 2005;45:212-213 (Article in Russian).

161. Milgrom LR, King KR, Lee J, Pinkus AS. On the investigation of homeopathic potencies using low resolution NMR T2 relaxation times: An experimental and critical survey of the work of Roland Conte et al. Br Homeopath J 2001;90:5-13.

162. Morozov A. Avogadro's number and homeopathy. Hom Links 2003;16:97-100.

163. Munshi GK. Identification of homoeopathic inorganic drugs by T.L.C. Hahnemann Glean 1983;50:450-451.

164. Nain AK, Droliya P, Manchanda RK, et al. Physicochemical studies of extremely diluted solutions (homoeopathic formulations) of sulphur in ethanol by using volumetric, acoustic, viscometric and refractive index measurements at different temperatures. J Mol Liquids 2015;211:10821094.

165. Pillai MG, Kumar A, Sharma R, Bhasin N. LC-MS based workflows for qualitative and quantitative analysis for homeopathic preparation of Hydrastis canadensis. Chromatographia 2014;77:119-131.

166. Rajendran ES. An evaluation of Avogadro's number in the light of HRTEM and EDS studies of high dilutions of Ferrum metallicum 6, 30, 200, $1 \mathrm{M}, 10 \mathrm{M}$ and 50Mc. Int J High Dilution Res 2015;14:3-9.

167. de Miranda AR. Water and High Dilutions Phenomenology: Physical Characterization. In: Bonamin LV (eds). Signals and Images. Dordrecht: Springer, 2008 Presented at $20^{\text {th }}$ Symposium of GIRI, São Paolo, 2006.

168. Rao ML, Roy R, Bell I. Characterization of the structure of ultra dilute sols with remarkable biological properties. Mater Lett 2008;62:1487-1490.

169. Rao ML, Roy R, Bell IR, Hoover R. The defining role of structure (including epitaxy) in the plausibility of homeopathy. Homeopathy 2007;96:175-182.

170. Resch G, Gutmann V, Schauer H. "The shaking effect" on the conductivities of liquids. J Ind Chem Soc 1982;59: 130-132.

171. Rey L. Thermoluminescence of ultra-high dilutions of lithium chloride and sodium chloride. Phys A 2003;323: 67-74.

172. Rey L. Can low-temperature thermoluminescence cast light on the nature of ultra-high dilutions? Homeopathy 2007;96:170-174.

173. Roder E, Frisse R. On the stability of homeopathic dilutions in glass and plastic containers. Pharmazie 1981;36: 615-619 (Article in German).

174. Röder E, Pütz W, Frisse R. Bestimmung von Au, Fe, Zn und $\mathrm{Hg}$ in homöopathischen Dilutionen durch zerstörungsfreie Neutronenaktivierungsanalyse. Fresenius Zeitschrift Anal Chem 1981;307:120-126.

175. Sacks AD. Nuclear magnetic resonance spectroscopy of homeopathic remedies. J Holist Med 1983;5:172-177.
176. Sarkar T, Konar A, Sukul NC, et al. Free water molecules and hydrogen bonding form the basis of variation in homeopathic potencies as revealed by vibrational spectroscopy. Int J High Dilution Res 2015;14:8-15.

177. Schilling T. Versuche zum Nachweis der physikalischen Kräfte der homöopathischen Arzneiform. In: LHI, ed. X. Kongress der Liga Homoeopathica Internationalis, Budapest. Budapest, Hungary; 1935:374-385.

178. Sharma A, Purkait B. Identification of medicinally active ingredient in ultradiluted Digitalis purpurea: Fluorescence spectroscopic and cyclic-voltammetric study. J Anal Methods Chem 2012;2012:109058.

179. Silvio M, Arnaldo P. Ultrasonic study of homoeopathic solutions. Br Hom J 1990;79:212-216.

180. Smith RB, Jr., Boericke GW. Modern instrumentation for the evaluation of homeopathic drug structure. J Am Inst Homeopath 1966;59:263-280.

181. Smith RB, Boericke GW. Continued research with modern instrumentation for the evaluation of homeopathic drug structure. J Am Inst Homeopath 1967;60:259-272.

182. Smith RB, Boericke GW. Changes caused by succussion on N.M.R. patterns and bioassay of bradykinin triacetate (BKTA) succussions and dilutions. J Am Inst Homeopath 1968;61:197-212.

183. Stephenson J, Brucato A. The effect of succussed macroand micro-dilutions of sodium thiosulfate $\left(\mathrm{Na}_{2} \mathrm{~S}_{2} \mathrm{O}_{3}\right)$ on supersaturated solutions of sodium thiosulfate. J Am Inst Homeopath 1960;53:94-95.

184. Sukul A, Sarkar P, Sinhababu SP, Sukul NC. Altered solution structure of alcoholic medium of potentized Nux vomica underlies its antialcoholic effect. Br Homeopath J 2000;89:73-77.

185. Sukul NC, Datta S, Sinhababu SP. Conformational changes of bovine serum albumin in $4 \mathrm{M}$ urea and ultra high dilutions of different drugs. Sci Cult 2007;73:173-175.

186. Sukul NC, De A, Dutta R, et al. Nux vomica 30 prepared with and without succussion shows antialcoholic effect on toads and distinctive molecular association. Br Homeopath J 2001;90:79-85.

187. Sukul NC, Ghosh S, Sinha Babu SP, Sukul A. Strychnos nux-vomica extract and its ultra-high dilution reduce voluntary ethanol intake in rats. J Altern Complement Med 2001;7:187-193.

188. Sukul NC, Ghosh S, Sukul A, Sinhababu SP. Variation in fourier transform infrared spectra of some homeopathic potencies and their diluent media. J Altern Complement Med 2005;11:807-812.

189. Sukul NC, Sinhababu SP, Datta SC, et al. Nematotoxic effect of Acacia auriculiformis and Artemisia nilagerica against root-knot nematodes. Allelopathy J 2001;8:65-72.

190. Süss WG. Struktur und Dynamik von homöopathischen Hochpotenzen-Resonanz-/Dämpfungs-/EntdämpfungsMessungen (REDEM). In: Süss WG, ed. Homöopathische Arzneimittel-wissenschaftliche Grundlagen für die Herstellung, Qualität und Anwendung. Stuttgart, Germany: Deutscher Apotheker Verlag; 2004:49-63.

191. Taufiq Khan M. Physical aspects related to the problems in potentised drugs. In: Seitschek R, ed. XXVIII. Internationaler Kongress für homöopathische Medizin. Vol Wien, May 28-June 2, 1973: Österreichische Gesellschaft für Homöopathische Medizin; 1973:473-479.

192. Tiezzi E, Catalucci M, Marchettini N. The supramolecular structure of water: NMR studies. Int J Des Nat Ecodyn 2010; 5:10-20. 
193. Upadhyay RP, Nayak C. Homeopathy emerging as nanomedicine. Int J High Dilution Res 2011;10:299-310.

194. van Wijk R, Bosman S, van Wijk EPA. Thermoluminescence in ultra-high dilution research. J Altern Complement Med 2006;12:437-443.

195. Veith H. Dynamik bewegter Flüssigkeiten. BM 1976;5: 123-125.

196. Walach H, van Asseldonk T, Bourkas P, et al. Electric measurement of ultra-high dilutions-a blinded controlled experiment. Br Homoeopath J 1998;87:3-12.

197. Weingärtner O. Homöopathie verstehen. Versuch eines naturwissenschaftlichen Zuganges. Therapeutikon 1988; 5(Mai):310-320.

198. Weingärtner O. NMR-Spektren von Sulfur-Potenzen. Therapeutikon 1989;3:438-442.

199. Weingärtner O. NMR-features that relate to homoeopathic sulphur-potencies. Berlin J Res Homeopath 1990; 1:61-68.

200. Weingärtner O. Homöopathische Potenzen. Wunsch und Wirklichkeit bei der Suche nach der therapeutisch wirksamen Komponente. Berlin, Germany: Springer Verlag, 1992.

201. Witt C. Versuch der Messung einer nichtstofflichen Information. In: Albrecht H, Frühwald M, eds. Jahrbuch Karl und Veronica Carstens-Stiftung. Vol 2. Stuttgart, Germany: Hippokrates, 1995:153-165.

202. Witt C. Physikalische Untersuchung homöopathischer Hochpotenzen. Essen, Germany: KVC Verlag, 2000.

203. Witt C, Ludtke R, Weisshuhn TE, Willich SN. High homeopathic potencies are different from potentized solvent when investigated with the REDEM technology. Forsch Komplement 2005;12:6-13.
204. Witt CM, Ludtke R, Weisshuhn TER, et al. The role of trace elements in homeopathic preparations and the influence of container material, storage duration, and potentisation. Forsch Komplement 2006;13:15-21.

205. Wolf U, Wolf M, Heusser P, et al. Homeopathic preparations of quartz, sulfur and copper sulfate assessed by UV-spectroscopy. Evid Based Complement Altern Med 2011;2011:Article ID 692798.

206. Wurmser L, Loch P. Recherches expérimentales sur les dilutions homoeopathiques. In: LHI, ed. X. Kongress der Liga Homoeopathica Internationalis Budapest 1935. Budapest, Germany. 1935:359-373.

207. Young TM. Nuclear magnetic resonance studies of succussed solutions. J Am Inst Homeopath 1975;68:8-16.

208. Zacharias CR. Implications of contaminants to scientific research in homoeopathy. Br Homeopath J 1995;84:3-5.

209. Zacharias CR. Contaminants in commercial homoeopathic medicines. Br Homeopath J 1995;84:71-74.

210. Albrecht $H$, van Wijk R, Dittloff S. A new database on basic research in homeopathy. Homeopathy 2002;91:162-165.

211. Stock-Schröer B. Reporting experiments in homeopathic basic research (REHBaR). Homeopathy 2015; 104:333-336.

Address correspondence to:

Alexander Tournier, PhD

Homeopathy Research Institute

124 Cromwell Road

London SW7 4ET

United Kingdom

E-mail: alextournier@hri-research.org 